\title{
Pest insect immigration warning system by an atmospheric dispersion model, weather radars and traps
}

\section{Leskinen, Matti}

2011-02

Leskinen, M , Markkula , I , Koistinen , J , Pylkkö , P , Ooperi , S , Siljamo , P , Ojanen , H , Raiskio , S \& Tiilikkala , K 2011, ' Pest insect immigration warning system by an atmospheric dispersion model, weather radars and traps ' , Journal of Applied Entomology , vol. 135 , no. 1-2 , pp. 55-67 . https://doi.org/10.1111/j.1439-0418.2009.01480.x

http://hdl.handle.net/10138/26290

https://doi.org/10.1111/j.1439-0418.2009.01480.x

publishedVersion

Downloaded from Helda, University of Helsinki institutional repository.

This is an electronic reprint of the original article.

This reprint may differ from the original in pagination and typographic detail.

Please cite the original version. 


\title{
Pest insect immigration warning by an atmospheric dispersion model, weather radars and traps
}

\author{
M. Leskinen ${ }^{1}$, I. Markkula ${ }^{2}$, J. Koistinen ${ }^{3}$, P. Pylkkö ${ }^{3}$, S. Ooperi ${ }^{4}$, P. Siljamo ${ }^{3}$, H. Ojanen ${ }^{2}$, S. Raiskio ${ }^{2}$ \\ \& K. Tiilikkala ${ }^{2}$ \\ 1 Department of Physics, University of Helsinki, Helsinki, Finland \\ 2 MTT Agrifood Research Finland, Jokioinen, Finland \\ 3 Finnish Meteorological Institute, Helsinki, Finland \\ 4 Department of Applied Biology, University of Helsinki, Helsinki, Finland
}

\author{
Keywords \\ Plutella xylostella, Rhopalosiphum padi, \\ aphids, long-range migration, polarimetric \\ radar

\section{Correspondence \\ Matti Leskinen (corresponding author) University of Helsinki, P.O. Box 64, F1-00014, Finland. \\ E-mail: matti.leskinen@helsinki.fi}

Received: August 28, 2009; accepted: October 31, 2009.

doi: $10.1111 /$ j.1439-0418.2009.01480.x

\begin{abstract}
In an experimental set-up in and around Helsinki, Finland $\left(60^{\circ} \mathrm{N}, 25^{\circ} \mathrm{E}\right)$, we have detected pest insect immigration using weather radars and insect traps in the field. This study was part of a project to develop a system to give warning of a possible arrival of long-range migrant insect pests. Bird-cherry aphid, Rhopalosiphum padi, and diamondback moth, Plutella xylostella, were found on the ground following migrations in warm airstreams at the end of May 2007. This migration episode was successfully forecast by the meteorologists in the project team. For the summer 2008, we developed a pest insect immigration alarm system based on SILAM, a Finnish Meteorological Institute atmospheric dispersion model. The first important pest insect immigration occurred in late June, bringing bird-cherry aphids. Our alarm system correctly produced a warning of this immigration. We studied the migration path in the observed events in 2007 and 2008 with the help of the atmospheric dispersion model. Weather radars frequently showed rain echo over the area, but there was also a lot of echoes originating from the migrating insects. Using the polarimetric weather radar in Helsinki, we could differentiate insects from other sources of echoes. Insects were common in layers below $1 \mathrm{~km}$, and were observed up to height of about $2.5 \mathrm{~km}$. Using Doppler weather radars we were able to observe the speed and direction of the migration. The experiment showed that an atmospheric dispersion model is an effective tool for predicting the movement of airborne migrants. The alarm system would work still better, if the sources of the immigrants were known in more detail. In addition, the very simple modelling of airborne migration should be refined. Weather radars, and especially polarimetric systems, are able to detect insect migrations and reveal details of the phenomenon not obtainable by other means.
\end{abstract}

\section{Introduction}

The long-range migration of insects is greatly facilitated by wind, and in general weather has a strong effect on take-off, flight and landing (e.g. Gatehouse 1997). Pest insects capable of long-range migrations are common, and may cause most of the losses in agricultural production (e.g. Irwin and Thresh 1988; Kurppa 1989b; Westbrook et al. 1995a,b). In many cases, the pest potential of the immigrants is enhanced by their acting as plant disease vectors. The threat by immigrating pests may further increase 
if they are from more aggressive strains, have developed insecticide resistance, or reproduce more and are better dispersers than their domestic counterparts.

Large annual changes of latitudes of many insect species occur mostly as successive migrations by a couple of generations, and not as back-and-forth displacements of individuals. Quite regular seasonal migrations have been observed in many moths and butterflies that are not able to overwinter in the higher latitudes where they occur during the summer (Mikkola 1967, 2003; Showers 1997; Chapman et al. 2008). Some of these migrations may even reach such remote areas as Svalbard (Coulson et al. 2002), with obvious loss of individuals from the population. Return migrations of butterflies and moths in the autumn to lower latitudes have also been observed (Mikkola 2003; Chapman et al. 2008). Weather radar observations in 1987, during a mass outburst of the bird-cherry aphid autumn generation, showed insect migration southeastwards from Finland (Nieminen et al. 2000).

Trajectories based on airstreams have long been used in studying insect migration cases (Mikkola and Salmensuu 1965; Scott and Achtemeier 1987; Wolf et al. 1987; Nieminen et al. 2000; Otuka et al. 2006). Modern meteorological analysis is based on numerical weather prediction (NWP) systems. For forecasting and studying the migration paths, we used SILAM, a Finnish Meteorological Institute (FMI) atmospheric dispersion model. Our studies concentrated on certain agricultural pests, the most important of these being the bird-cherry aphid (Rhopalosiphum padi), the diamond-back moth (Plutella xylostella) and the Colorado potato beetle (Leptinotarsa decemlineata). The aphids overwinter in Finland as eggs, while the moths are regular immigrants that are not expected to be able to overwinter locally. The beetles are quarantine pest insects, which means that no permanent local populations exist in the country. In 1998 and 2002, significant infestations were detected in southern Finland following aerial migrations of the beetles, but there were no such immigrations during our experiment.

Aphid migrations to Finland have been a regular cause of concern among national pest control agencies. One of the most severe cases of aphid immigrations happened in May 1988, mainly involving birch aphids, Euceraphis betulae and bird-cherry aphids (Nieminen et al. 2000). The bird-cherry aphid can cause considerable damage to cereals. Besides its direct damage, it is also a vector of the barley yellow dwarf virus (BYDV). Rhopalosiphum padi overwinters in Finland on the bird-cherry, Prunus padus, by laying winter eggs (Kurppa 1989a). The winged adults migrate to grasses in the spring or early summer. The local population is monitored during the winter by counting the density of surviving eggs in the trees. These counts are then used for forecasting infestation levels in the spring (Kurppa 1989a). In 1988, the Finnish population of $R$. padi was numerous, following a population maximum in the previous autumn. But, in May 1988, a couple of weeks before the local populations were due to move to the fields, a massive immigration of these aphids occurred (Kurppa 1989a; Nieminen et al. 2000).

At the end of May 1995, the immigration of P. xylostella was unusually heavy, and the timing of the migration was exceptionally early. This caused a considerable crop failure in Finland and in Sweden (Tiilikkala et al. 1996). The first generation caterpillars in Finland lived on brassica weeds, and the resultant adults started to lay eggs just when turnip rape was in the seedling stage. The next generations lived on other brassicas. In some areas, there were as many as four generations, which is very exceptional in Finland. Another mass immigration of diamond-back moths took place at the beginning of June 1997. At the end of 1990s, diamond-back moth immigrations were detected by weather radars (Tiilikkala et al. 1996). In 1997, due to the rapid detection of the migration by a weather radar and identification of the moths in the fields by pest control experts, the farmers were able to take steps to control the moths in good time.

Entomological radars have been used mainly in special field studies on severe pest insects; these studies have been reviewed, e.g. by Riley (1989). Vertical-looking entomological radar systems have been used for long-term monitoring purposes (Beerwinkle et al. 1995; Smith et al. 2000; Chapman et al. 2002a). Weather radar echoes from insects have also been used in migration studies (Irwin and Thresh 1988; Nieminen et al. 2000; Lang et al. 2004). Our experiment is connected to a larger research project studying the applications of polarimetric weather radar, in which we have used the dual polarization radar in Helsinki for monitoring insect migration. Since the 1980s, weather radar detection of insect migrations has regularly been used in reports of insect migrations in Finland (e.g. Mikkola 1996). Polarimetric capabilities make the observing of insect migrations by weather radars more reliable. 


\section{Materials and Methods}

Insect traps, and analysis of the catches

During summer, two suction traps are operated at Helsinki (Viikki) and Jokioinen in southern Finland by MTT (Agrifood Research Finland); these are part of a European network of suction traps with twiceweekly sampling. These suction traps provided us with quasi-quantitative data on migrating insects at the trap inlet level $12 \mathrm{~m}$ above ground. There are known efficiency reductions in the suction traps related to trap inlet size, insect size, and wind speed (Taylor 1962). In this experiment, we also used extra tow-net and yellow sticky traps with two protocols in insect trapping; continuous monitoring and migration alarm trapping. Migration alarm trapping was conducted when meteorologists in the project predicted a significant immigration - in 2008 utilizing a special migration forecast model. The trap sites are shown in fig. 1 in relation to the University of Helsinki (UH) polarimetric weather radar $\left(60.20^{\circ} \mathrm{N}\right.$, $\left.24.96^{\circ} \mathrm{E}\right)$.

For continuous monitoring, we used six rotating tow-nets and five yellow sticky traps. Five of the rotating tow-nets were situated on a line JokioinenViikki about $2 \mathrm{~m}$ above the ground in open fields. One tow-net was on the roof at Kumpula about $25 \mathrm{~m}$ above ground level. The tow-nets rotated freely on tripods so that their circular inlets, $1 \mathrm{~m}$ in diameter, were always directed into the wind. Cloth bags collected the insects, which fell into a sample bottle containing $70 \%$ alcohol. On the fields, the tow-nets were sited so as to be easy to reach, at the

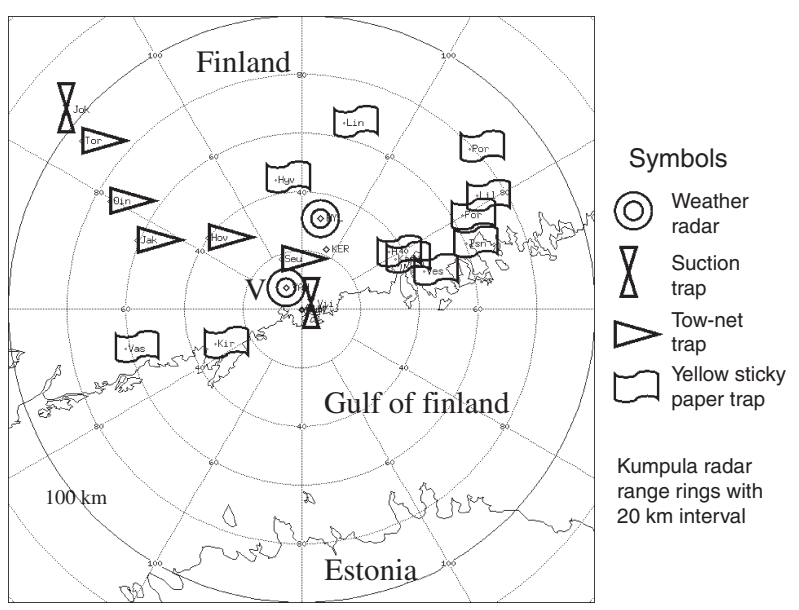

Fig. 1 Insect trap sites inside the Kumpula radar range, and the FMI Vantaa (V), and UH Järvenpää (J) radar sites. edges of fields and in places where they would not disturb the agricultural work. At five tow-net sites, we also had sticky traps; catches from both trap types were removed for analyses at the same time. During a migration alarm, we placed extra yellow sticky traps at six more sites in the area. They were usually set in the morning and collected the next day. The distance of the extra sticky traps from the Kumpula radar was between 20 and $60 \mathrm{~km}$ (fig. 1).

All the tow-nets were in service from the beginning/middle of May to the end of June in 2007 and 2008. Suction trap samples were examined according to their routine operation, in which the sample bottles are emptied on to Petri dishes to identify the insects. The tow-net samples were treated in a similar manner. All the sticky papers were photographed for possible future analyses. The papers were then taken to a freezer to kill the insects. After freezing, the traps were covered with a transparent plastic for examination and storing. The insects were examined under a microscope. All the most important pest species were identified as exactly as possible, while other insects were identified to the level of families.

\section{Weather radar observations of insects}

Radar measures the properties of echoes returned from its transmitted pulses that are directed by its antenna into the surroundings. We used the C-band (5 cm wavelength) Doppler weather radars in southern Finland. The closest radar locations can be found in fig. 1 showing the study area, the FMI's Anjalankoski and Korpo sites are shown in fig. 4. The UH operates two radars for research purposes, the Kumpula radar in Helsinki being a dual polarization radar that can transmit and receive both horizontally and vertically polarized radiation. The other UH radar and the FMI radars used only horizontally polarized transmitting and receiving. The main parameters of these systems are roughly the same, the Kumpula radar information is presented in table 1 .

The most important quantity in weather radar measurements is the radar reflectivity, which is used for quantitative precipitation estimation (e.g. Battan 1973). The reflectivity is calculated from the average received power of the echo. A huge number of precipitation particles contribute simultaneously to the echo signal. Averaging of the received signal over some tens of transmitted pulses is needed to reduce the effect of random fluctuations to an acceptable level. Weather radar echoes can also be produced by a 
Table 1 Kumpula radar system characteristics

\begin{tabular}{ll}
\hline Transmitter frequency & $5600-5650 \mathrm{MHz}$ \\
$\quad$ (licensed range) & \\
Transmitter pulse peak power & $250 \mathrm{~kW}$ \\
Transmitter pulse length & Short: $0.6 \mu \mathrm{s}$, long: $2.3 \mu \mathrm{s}$ \\
Transmitter pulse repetition & $200-2400 \mathrm{~Hz}$ \\
rate (short pulse) & \\
Antenna type & Centre-fed parabolic \\
& reflector \\
Antenna reflector diameter & $4.2 \mathrm{~m}$ \\
Antenna beamwidth & $1.05^{\circ}$ \\
Antenna gain & $44.5 \mathrm{~dB}$ \\
Receiver minimum detectable & $-115 \mathrm{dBm}=5 \mathrm{fW}$ \\
power (long pulse) & $\left(5 \times 10^{-15} \mathrm{~W}\right)$ \\
Maximum range to detect a & $4 \mathrm{~km}$ \\
single Plutella xylostella moth & \\
\hline
\end{tabular}

mixture of insects in the radar pulse volume; the reflectivity increases with both an increase in the number density of insects and with an increase of the size of the individuals (e.g. Riley 1985; Vaughn 1985).

Insects, including $P$.xylostella, that are large enough can be observed by weather radars as single targets. The range of detection in table 1 is based on the data in Chapman et al. (2002b) taking into account the difference in radar wavelength. In the case of small insects, there have to be many in the radar measuring volume to cause detectable echoes. As the $R$. padi aphids are small, and the long-range migrants are even smaller than average (Wiktelius 1982), it may be doubted whether their number density during migrations is high enough for detection at all (Nieminen et al. 2000). However, in all mass migrations of $R$. padi detected by traps in Finland there have been plenty of radar echoes from insects, even if the major contributors were other species. Meteorological radars used in cloud research are more sensitive than weather radars for small targets, and Wood et al. (2009) used cloud-radars to gather information on small insects as well.

A Doppler weather radar measures radial speed, and if that quantity is measured around the radar, the average horizontal direction and speed of the scattering media can be calculated. During insect migration, this method is used to get an estimate of migration direction and speed. A polarimetric weather radar measures a number of additional quantities as well. Differential reflectivity and co-polar cross-correlation coefficient were used in our study. These quantities significantly help in separating insects from other scattering media as the cause of echoes (Zrnic and Ryzhkov 1998; Lim et al. 2005). The body orientation in relation to the axis of polarization of the radar radiation has its effects on radar echoes; this has already been utilized for a long time to observe the collective orientation of migrating insects (Riley 1975; Irwin and Thresh 1988; Nieminen et al. 2000; Chapman et al. 2008). Observations of insects by polarimetric weather radars have also been of meteorological interest (Mueller and Larkin 1985; Achtemeier 1991; Wilson et al. 1994).

Due to the Earth's curvature, the radar beam gets higher up as the range increases. In Finland, weather radars observe insect migrations within the lowest $3 \mathrm{~km}$ of the atmosphere, typical temperature at the insect layer top appearing to be about $+5^{\circ} \mathrm{C}$. In cool weather, the top level of migration may stay below $500 \mathrm{~m}$; this is also typical for small nocturnal migrants taking off after sunset. In such conditions, even the lowest radar beam elevation already overshoots the layer of insects at a range of $50 \mathrm{~km}$.

\section{Meteorological data and immigration modelling}

The archive of meteorological data for our study covers the summers of 2007 and 2008 from May to the end of June. We collected NWP data as well as satellite observations, for analysing the meteorological circumstances of the migration events. The NWP models used were HIRLAM (Unden et al. 2002) and ECMWF (2009). For estimating migration pathways, we used the air quality and emergency dispersion modelling system SILAM developed in FMI. This is capable of both forward and inverse simulations, for which Lagrangian and Eulerian dynamic cores are available (Sofiev et al. 2006b, 2008).

The SILAM system has been used for pollen applications since 2005 for both source apportionment and forward dispersion simulations (Sofiev et al. 2006a; Siljamo et al. 2007, 2008a,b). We conducted inverse simulations to the immigration observation site at Kirkkonummi, $32 \mathrm{~km}$ WSW of the Kumpula radar. The SILAM system used a 15-min time step, and evaluated $60 \mathrm{~h}$ backwards in time for each case. The horizontal resolution was $30 \mathrm{~km}$ and the area of the simulations covered practically the whole of Europe. The Eulerian dynamic core of SILAM evaluated a complete adjoint dispersion equation and also included removal processes, wet and dry deposition. We simulated pest insects as tiny particles $(2.5 \mu \mathrm{m}$ diameter); typical long-range transported particles in the atmosphere.

In the 2008 alarm runs, the dispersion model used for pollen was replaced by a specific dispersion model for bird-cherry aphids and diamond-back 
moths. Insects were modelled as particles in the same way as in the inverse simulations. The length of computations was $78 \mathrm{~h}$ (from -1 day to +2 days). The source area of the insects was the whole area limited by the latitudes 50 and $60^{\circ} \mathrm{N}$, and the longitudes 20 and $45^{\circ} \mathrm{E}$. The amount of migrants taking off was weighted using a land-sea mask for diamond-back moth and the fraction of birch for birdcherry aphid. Fraction of birch was used, because birch and bird-cherry were found to grow in about the same area and the data on birch were already available for the model for pollen transport.

We used the timing of insect migration take-off as one input into SILAM, using a table in l-h steps to determine the proportion of the migrants relative to the daily total. The tables were formulated differently for R. padi and P.xylostella following certain studies found in the literature. In principle, the aphids are daylight-active (Wiktelius 1981), while the moths take-off $\mathrm{l} \mathrm{h}$ after sunset (Danthanarayana 1986). The observed two peaks in the flight activity of aphids (Wiktelius 1981) were not included in this modelling of long-range migration. However, the scheduling of take-off was according to the model time (UTC) over the whole source area, and the timing was not changed during the alarm experiment. Figure 2 shows the take-off distributions for the two species.

At the beginning, we propagated the modelled insects in the air layer between altitudes at 200 and $500 \mathrm{~m}$. The index for insect immigration was computed as a $2-h$, area and vertical average, so that the target area was inside a box with a vertical extent of

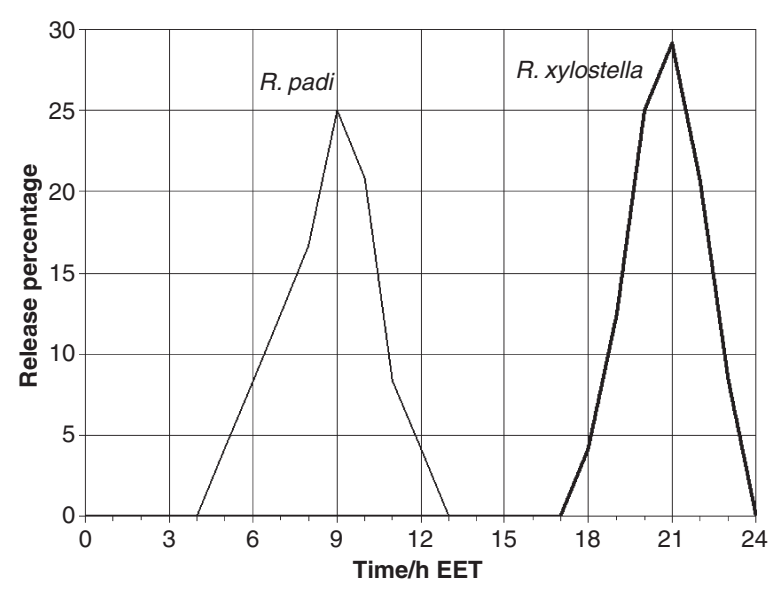

Fig. 2 Insect take-off schedules for Rhopalosiphum padi and Plutella xylostella in the 2008 ASIM-model in Eastern European time, the local time at $30^{\circ}$ East longitude. up to $2 \mathrm{~km}$; however, insects present at altitudes from the ground to $650 \mathrm{~m}$ made the main contribution to the index. The quantity given by SILAM for each province in southern Finland was converted into an index value between 0 and 4 . The value was zero, if the temperature in the source area was $<10^{\circ} \mathrm{C}$. The calculus was adjusted using some statistics of typical results by SILAM. Those statistics gave the maximum limits for each province, which were assigned an index value of 4 , indicating high probability of insect immigration and thus a severe warning. Other index values from 1 to 3 were then assigned evenly.

\section{Results}

Migrations and pests in the traps in May 2007

The main immigration of bird-cherry aphids occurred in Finland 24-28 May 2007, as shown in fig. 3. Hundreds of aphids were trapped in townets during this period. The maximum number was 166 at Oinasjärvi, roughly $80 \mathrm{~km} \mathrm{NW}$ of Helsinki. However, in the next period, the maximum of these aphids appeared near the coastline in the Kumpula tow-net and Viikki suction trap. The 'domestic' bird-cherry aphids were still on the overwintering host (Prunus padus) (MTT unpublished monitoring data) during the immigration period. The first two aphids already appeared in the Kumpula tow-net in the sample 14-16 May, and were probably extremely long-range migrants. At this time, airstreams from the $\mathrm{S}$ and SW also brought long-range migrant red admiral butterflies, Vanessa atalanta, to Finland (Luonnontieteellinen Keskusmuseo 2009).

Data from the Swedish suction traps (R. Sigvald, personal communication) show that maxima of $R$. padi migrants were observed during the warm airflow from the E-SE across the Baltic at the end of May. Maximum numbers were observed on the island of Gotland (Stenstugu, $500 \mathrm{~km} \mathrm{SW}$ from Helsinki) in the period 28-30 May, about three times more than in other Swedish traps or in the Finnish suction trap in Helsinki (Viikki). In suction trap in St. Petersburg area (Pushkin, $300 \mathrm{~km} \mathrm{E} \mathrm{from}$ Helsinki), the first trap catches of $R$. padi were on 28 May, but only 12-15 aphids were caught before 15 June (R. Sigvald, personal communication).

Diamond-back moths were caught in sticky traps near the coastline on 28 May 2007, and in the Kumpula tow-net during the first days of June. The number of moths in our traps did not exceed the 


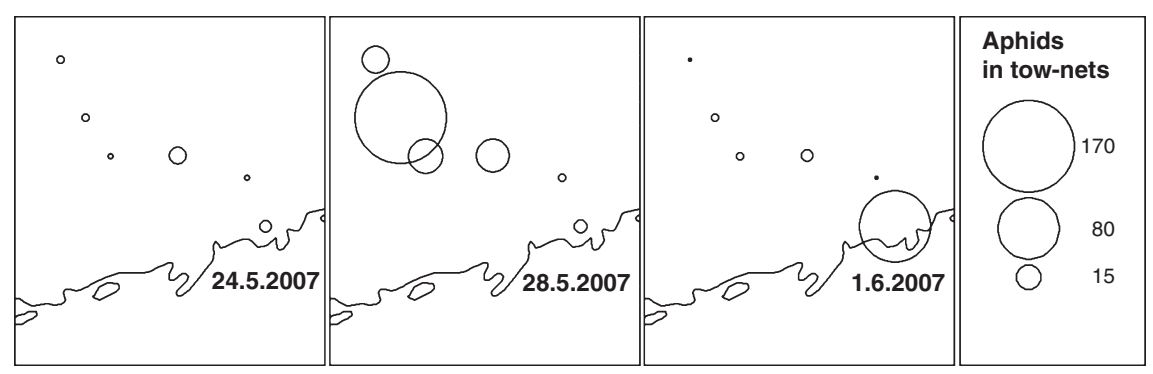

Fig. 3 Bird-cherry aphids in tow-net traps in southern Finland during the period from 24 May to 1 June 2007.

pest alarm limit, but diamond-back moths were more numerous in southeastern Finland, and started to be observed by farmers on 30 May (A. Piirainen, personal communication). These localities in eastern Finland are $200-300 \mathrm{~km}$ NE of our study area; during the migration period, the warmest air mass from the south or southeast was flowing east of Helsinki area. The moths that arrived in eastern Finland were able to lay eggs, but a subsequent rainy period caused high mortality among the progeny. The second-generation immigration was observed in southwestern Finland on 7 July. Those insects probably originated from areas E-SE of Finland, where the migration at the end of May was characterized by longer lasting favourable airstreams than those present in eastern Finland.

The Finnish entomological database (Luonnontieteellinen Keskusmuseo 2009) shows some observations of single P.xylostella on 26-27 May in our study area, but larger groups of the moths were observed from 29 May onwards. Twenty-five moths were observed by P. Pakkanen on 30 May near the Järvenpää radar site $32 \mathrm{~km}$ NNE of Kumpula, while M. Leskinen noticed two moths making short flights beside the radar the next day. A total of 1500 diamond-back moths were collected by J. Kullberg on the island of Örö in SW Finland during the period from 29 May to 12 June.

\section{Weather and radar analysis in 2007}

At the end of May, a warm air mass with daytime maximum temperatures well above $+25^{\circ} \mathrm{C}$ prevailed in areas south and southeast of Finland during the week before the insects' arrival in Finland. Mostly sunny weather prevailed in the warm air mass, with a well-mixed boundary layer during the daytime. Low static stability of the air produced occasional local thunderstorms and more extensive mesoscale convective systems, causing some rain, but on average the local insect popula- tions in a direction south and southeast of Finland experienced favourable conditions for growth and migration.

During 27-29 May, a large slowly moving frontal cyclone developed in Central Europe, pushing warm air towards the northwest from the Baltic States and Russia. The warm front reached the southern coast of Finland on 28 May, and remained there quasi-stationary for 2 days. The warm inflow culminated on the afternoon of 29th, when the temperature reached $+27^{\circ} \mathrm{C}$ at several locations close to the southern coast of Finland, and $+30^{\circ} \mathrm{C}$ widely over Estonia. The surface front bent back southwards on the evening of 30 May, so that close to ground level the wind direction was typically from the ENE and the temperatures $10-14^{\circ} \mathrm{C}$ less than during the day before. Although the favourable flow at the surface ceased, it still continued for a while at higher levels, as seen from the atmospheric soundings from Jokioinen in southern Finland, Tallinn in Estonia and St Petersburg in Russia.

The migration of insects over the Gulf of Finland started to appear in weather radar observations on 26 May. At first the migrants came from southwesterly or westerly areas. The next day, migrants were coming from the S-SSW, although the flow gradually turned to also bring insects from the SSE. After a large precipitation area had moved northwards through the area during the night of 27-28 May, we observed strong insect migration below $1 \mathrm{~km}$. The flow was then from the east near the surface, but from the south at a height of $1 \mathrm{~km}$. At sunrise, the near-surface flow had its maximum at the 200-m level from the ENE at $13 \mathrm{~m} / \mathrm{s}$. Insect migration was a little weaker in the morning as a band of rain showers passed the area.

During 28-29 May, the flow near the surface brought insects from the sector E-NE, but at higher levels below $1 \mathrm{~km}$ the flow was from the ESE-S. Above this level, plenty of insects appeared up to an altitude of $2-2.5 \mathrm{~km}$; they were mostly still in a 
SSW-SW airstream. The number of insects was modified by some rain bands and cells, and on the afternoon of 28 May a strong rain band moving towards the NNE developed, blocking migration to the Helsinki area in the upper layers from the S-SSE, and later in the lower layers from the E. However, migration continued in the close vicinity of the rain areas. A typical speed of the migrants was 7-12 m/s. The daytime maximum speed on 28 May was $17 \mathrm{~m} / \mathrm{s}$ from the SW at an altitude of $2.0-2.5 \mathrm{~km}$. On the evening of the 29th, a wind maximum developed at the 400-600 m level, bringing migrants from the E-SE at $17 \mathrm{~m} / \mathrm{s}$.

Figure 4 shows an FMI weather radar network composite image of insect migration about $2 \mathrm{~h}$ before noon (08:30 UTC), and fig. 5 is a Kumpula radar vertical cross-section over the Gulf of Finland at the same time. The satellite image in fig. 6 displays the cloud systems at this time, showing that a clear weather area extended from southern Finland to the ESE-SSE sector, facilitating an uninterrupted flow of migrants. The yellow tinted areas north of the Gulf of Finland indicate a low cloud layer in the warm front area, while white and bluish-white areas show the position of high clouds, most of which were related to precipitation on the ground.

The most suitable weather for the long-range migration of $R$. padi and P.xylostella was therefore from the night of 27-28 May to late evening on the 29th. It is probable that the main $R$. padi migration occurred in the air mass transition between the 27th and the 28th. The delayed appearance of $R$. padi in the traps near the coast was directly related to the wind turning to bring insects from the Finnish mainland, i.e. from the ENE-NE near the surface. These aphids might have been immigrants on more local flights, or they may have descended near the coast from higher layers coming from the ESE-SE. For P. xylostella, that are probably able to continue migration after the first long-range flight, the easterly flows at the beginning of June may have been carrying the moths onwards from the main target area in the east of Finland.

\section{Midsummer aphid immigration in 2008}

Small numbers of bird-cherry aphids were caught in tow-nets during the first half of June in 2008. A sudden change happened on 23 June, when the numbers of this species jumped from a few to hundreds. The numbers of aphids in tow-nets varied from 33 to 730 . After 3 days, the numbers of aphids were much less, from 3 to 104 individuals. Based on the overwintering population, the pest forecast in 2008 predicted, with one or two exceptions, only small amounts of bird-cherry aphids. The domestic population usually goes from Prunus hosts into the fields in the first part of June, and during midsummer winged aphids are not seen in the traps. Thus, it is probable that the late peak in the number of aphids was caused by long-range migrants.

The radar observed insect migration during the period 20-24 June coming from the SW-SSW with varying intensity. There were a lot of rain areas, but in many cases strong migration of insects could

Fig. 4 FMl radar composite at 29 May 2007 08:30 UTC. Radar sites at Korpo (K), Vantaa (V) and Anjalankoski (A) are seen in the centres of the insect echo areas around them. Heavy thunderstorms in the west, and some weaker showers NW of Anjalankoski cause stronger echoes. Reflectivity colour scale is inserted in the lower right corner.

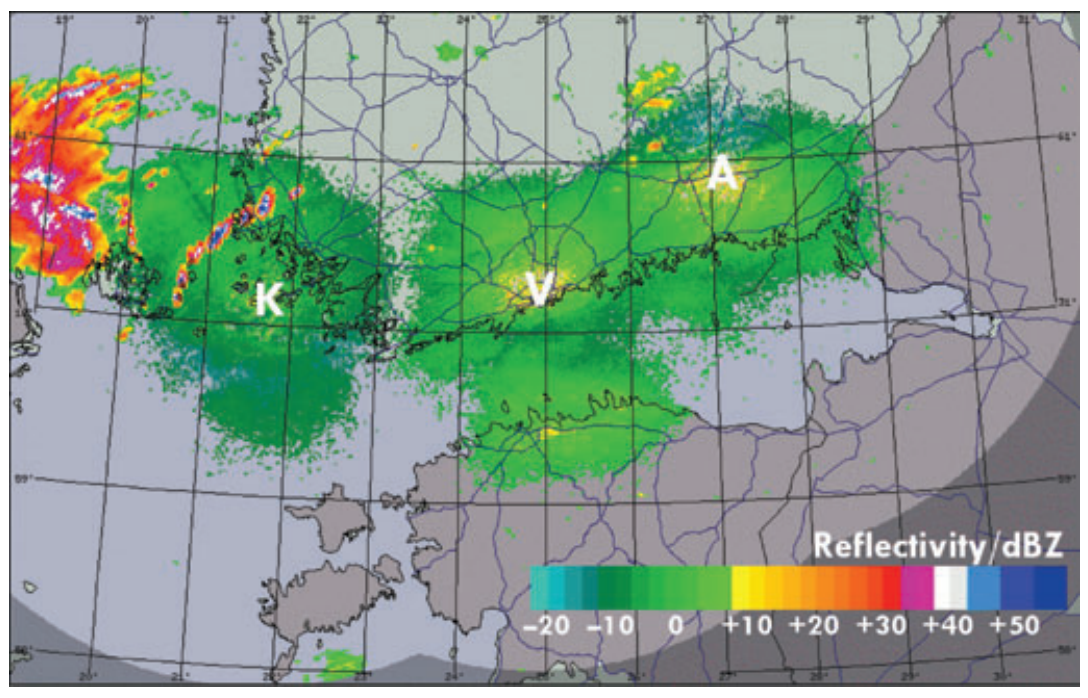




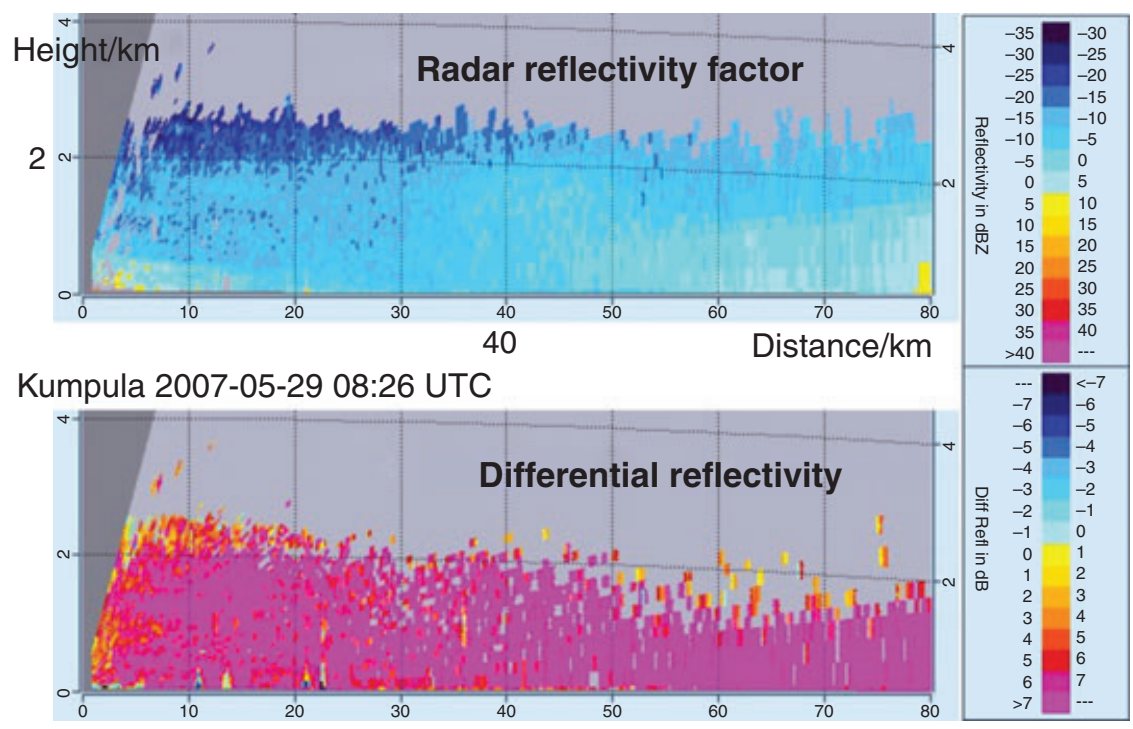

Fig. 5 Kumpula radar vertical cross-section of radar reflectivity factor (dBZ) top and differential reflectivity (ZDR) bottom at 29 May 2007 08:26 UTC. The cross-section azimuth is towards the south, mostly over the Gulf of Finland. ZDR is above $+7 \mathrm{~dB}$ in most of the echo due to the horizontal orientation of the elongated bodies of the insects, reflectivity is highest near the Finnish coast on the left and the Estonian coast on the right.

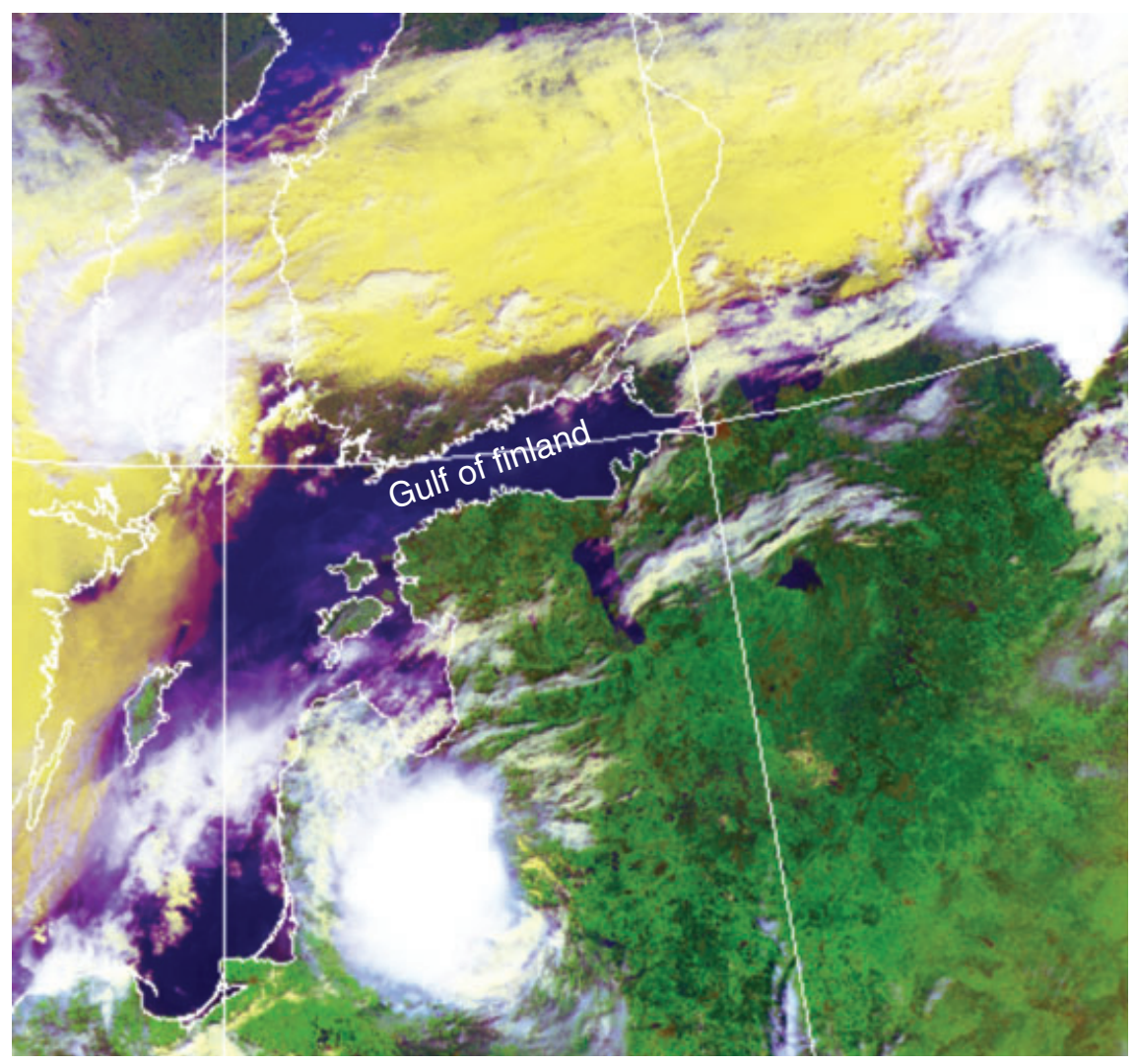

Fig. 6 Satellite Metop AVHRR composite image at 29 May 2007 08:26 UTC. The overlay map shows the meridians at $20^{\circ}$ and $30^{\circ} \mathrm{E}$, and latitude $60^{\circ} \mathrm{N}$ with the coastline of the Baltic, and the land border between Finland and Russia. 
be seen right up to the edges of the precipitation. Already after midnight on the 20th, large numbers of insects were seen coming over the Gulf of Finland from the SW, below $500 \mathrm{~m}$ at speeds of $7-$ $12 \mathrm{~m} / \mathrm{s}$. After some morning rain, insects migrated in large numbers from the SW at $12-15 \mathrm{~m} / \mathrm{s}$ below $1.5 \mathrm{~km}$ between the rain areas. In the evening, the rain was more frequent and migrating insects appeared congregated in the clear weather areas. Migration was generally weaker on the following days. On the 22nd, insects were observed over the Gulf of Finland coming from the WSW; an extreme long-range migration over the large areas of water. Before noon on 23 May, quite a lot of insects arrived from the south below $0.5 \mathrm{~km}$ at $10-12 \mathrm{~m} / \mathrm{s}$ ahead of precipitation, and, according to the trap data, it was probably at this point that the immigrant $R$. padi arrived.

\section{SILAM results and alarm indices}

The first approximation of the automatic insect alarm index was developed in spring 2008. The SILAM model (based on weather prediction model data from HIRLAM) gives the number of potential particles reaching the given target areas. At the end, the index values were calculated for cases of known migration, and these preliminary results were used for adjusting the index. The alarm indexes were also calculated using the ECMWF model fields for the special cases of summers 2007 and 2008 (24 May-1 June and 7th July 2007, as well as 19-23 June 2008). Comparing the results from these two different models indicates that the SILAM characteristics of dispersion may change from one NWP model to another. Also, of course, differences in the atmospheric forecasts between the two models affect dispersion as well.

We also used SILAM to validate the alarms of the three cases mentioned above. The target area was defined and then dispersion calculated backwards using the model field. In this way, it is possible to delimit the source areas of the particles simulating the insect movements. The results of all three cases are well in accordance with the original assumption: In May 2007, the insects originated from the Baltic and from the Karelian Isthmus, while in June 2008 they came from the southwest and the Baltic countries. This all confirms the results of our radar analysis. Trajectories to the Kirkkonummi trap (24-h period sample) are shown in fig. 7 based on the backwards calculation by SILAM using ECMWF data.

\section{Discussion}

\section{Insect migration forecasts}

Our results show that fruitful warnings of longrange migrations of pest insects can be based on NWP and atmospheric dispersion model. A better understanding of the conditions in the source area would provide better estimates of the start time and the intensity of insect migrations. Using soil moisture and land surface, temperatures derived from remote sensing as well as the state of the vegetation, for instance, would provide some keys with which to model the onset of migrations. Temperature thresholds should also be taken into account when estimating the ability of insects to take-off. In our alarm system, we introduced some post-processing that discarded putative migrations, if the air temperature turned out to be too low. The number of model migrants was also reduced if their flight-paths crossed precipitation areas.

The take-off of daylight migrants follows the rapid change in solar radiation and temperature in the morning, while nocturnal migrants are triggered very precisely by sunset (Gatehouse 1997). The most serious negative effect of the simple formulation of take-off in the migration forecast model is probably its lack of changing synchronization with local time. Moreover, the time of dawn and dusk are constantly changing relative to the UTC time. Daylight-active insects are not supposed to fly during the night, and nocturnal insects are supposed to land before dawn. In our modelling, this kind of diurnal flight periodicity was not included. Insects were allowed to continue their flight after take-off.

Despite the periodicity, terrestrial insects are expected to continue their flight above water as long as they can. The observations of P. xylostella at Svalbard (Coulson et al. 2002) showed that the moths continued flight during the day, and also below the temperature threshold normally related to their flight in the atmosphere (Chapman et al. 2002b). In addition, trajectories related to birch aphid migration into Finland suggested that the insects had flown over night above the Baltic (Nieminen et al. 2000). Radar observations revealed that aphids had obviously migrated through the night over the continental United States (Irwin and Thresh 1988) and in India (Riley et al. 1995). It should also be kept in mind that the migration episodes that we studied occurred in Finland, at the time of the year when there was no astronomical darkness during the night. 



Fig. 7 SILAM model estimates of trajectories to the trap in Kirkkonummi (black dot) in May 2007 and June 2008. The colour scale is related to the probability of trajectories started at the first time in the legend, and ended in Kirkkonummi during a 24-h period preceding the second time in the legend. The suction trap locations in Pushkin (P), Viikki (H), Jokioinen (J), Tyrnävä (T), Umeå (M), Ultuna (U), Kölbäck (K), Stenstugu (S), Ingelstorp (I), Alnarp (A), Växsjö (V) and Lanna (L) are shown on the 2007 case map.

\section{Applications}

In general, the better that pest immigrations are predicted and detected, the more efficient are the control measures in agriculture or forestry. Especially when using biological control agents, the extra time provided by a good immigration alarm system is important (Atlamaz et al. 2007). The development of early warnings could be a part of national action plans related to implementation of EU pesticide policy.
The warmer conditions that have been predicted by climate change models (IPCC 2007) may help many pest species to invade northern temperate countries, like Finland. The local population of $R$. padi could also have a better winter survival rate, and overwintering of P.xylostella could be expected farther north than at the moment. However, the possible increase in summer rain in Northern Europe would kill more eggs or larvae of the moths in Finland than now, and the lack of snow cover 
during the winter might cancel out the advantage of a warmer climate. For R. padi, the milder winter may also cause harmful effects if the bird-cherry trees become more ice covered due to more frequent melting-freezing fluctuations during the winter.

It would be feasible to monitor pest species that are at present just occasional visitors, but which could establish themselves permanently and cause pest outbreaks. Some of these pests, for example the Colorado potato beetle, have a quarantine status that obligates national authorities to arrange adequate surveillance. In the Northern European forest sector, such occasional visitors are, for example the nun moth (Lymantria monacha) and the gypsy moth (Lymantria dispar) (Vanhanen et al. 2007) both of which cause pest outbreaks in Central Europe, but still occur in Finland in only very low numbers. As both species are extremely polyphagous, there is vast amount of habitat available for their establishment and further spread.

Migration surveillance might also be applied to mass-migrating insect species carrying pathogens of plant diseases. Rhopalosiphum padi can carry BYDV from abroad. In fact, BYDV is a complex of six different viruses, which are carried in the salivary glands of aphids, and transmitted in feeding to new hosts. As aphids are responsible for the spread of these viruses, the above-described aerial surveillance system could be used to identify when these potential virus-carriers migrate from southern latitudes to northern areas. This latitudinal migration phenomenon takes place not only in Europe but also in North America (e.g. Irwin and Thresh 1988), and therefore an early warning system for farmers could form a novel and integral part of a plant-virus management scheme both within the United States and between European countries.

\section{Weather radar observations}

Weather radars are not so well-adapted to insect migration monitoring as are entomological radars, but they are already available as networks. A Europe-wide weather radar network can provide similar information as in our study. Weather radars are used for mapping the location of rain, which is also important in pest insect management. Doppler weather radars can detect insect migrations, and give information on the direction and speed of migrants in various air layers. Compared to other weather radars a polarimetric system is a significantly more reliable tool for automatic insect migration detection because of facilities such as dif- ferential reflectivity, which help in separating insects from other causes of echoes. Polarimetric weather radars will inevitably increase our knowledge of insect migrations, and a multidisciplinary approach could open up new avenues for further research and development leading to operational applications.

\section{Experience from end users}

During the summer of 2008, we had a group of seven pilot users of the warning service. They were from Nylands Svenska Lantbrukssälskap, the Farma Rural Development Center, the ProAgria Association of Rural Advisory Centres and the UH. Pilot users got access to both weather and insect information as well as being able to check the warning web site. In principle, a warning would have been issued via mobile phones as well, but in 2008 no such large migrations occurred during the reporting period. The experiences of the first summer were brought together in the autumn in a workshop especially planned for the pilot users. Basically, the pilot users considered the service useful and interesting. Still, the summer of 2008 was unfavourable from the point of view of insect pests and it is therefore difficult to judge the usefulness in great detail. The main message was that this kind of warning service should be in operation for several years, because massive invasions take place very irregularly, and so it takes a long period of time to accumulate data to refine the predictions.

\section{Acknowledgements}

This research has been funded by TEKES. Professor Kauri Mikkola has provided us with plenty of ideas and material at the outset of the project. Outi Järvinen and Timo Tolonen in the analysis team in MTT had a great deal of material to be analysed. The pilot user community was alert and ready to take the necessary actions, but fortunately no alarms were needed in 2008. Referees of the manuscript had valuable comments, and pointed out a couple of useful references for our study.

\section{References}

Achtemeier GL, 1991. The use of insects as tracers for "clear-air" boundary-layer studies by Doppler radar. J. Atmos. Oceanic Technol. 8, 746-765.

Atlamaz A, Zeki C, Uludag A, 2007. The importance of forecasting and warning systems in implementation of 
integrated pest management in apple orchards in Turkey. EPPO Bull. 37, 295-299.

Battan LJ, 1973. Radar observation of the atmosphere. The University of Chicago Press, Chicago/London.

Beerwinkle KR, Lopez JD Jr, Schleider PG, Lingren PD, 1995. Annual patterns of aerial insect densities at altitudes from 500 to 2400 meters in East-Central Texas indicated by continuously-operating vertically-oriented radar. Southwest. Entomol. 18(Suppl.), 63-70.

Chapman JW, Smith AD, Woiwod IP, Reynolds DR, Riley JR, 2002a. Development of vertical-looking radar technology for monitoring insect migration. Comput. Electron. Agric. 35, 95-1 10.

Chapman JW, Reynolds DR, Smith AD, Riley JR, Pedgley DE, Woiwod IP, 2002b. High-altitude migration of the Diamondback moth Plutella xylostella to the U.K.: a study using radar, aerial netting, and ground trapping. Ecol. Entomol. 27, 641-650.

Chapman JW, Reynolds DR, Mouritsen H, Hill JK, Riley JR, Sivell D, Smith AD, Woiwod IP, 2008. Wind selection and drift compensation optimize migratory pathways in a high-flying moth. Curr. Biol. 18, 514-518.

Coulson SJ, Hodkinson ID, Webb NR, Mikkola K, Harrison JA, Pedgley DE, 2002. Aerial colonization of high Arctic islands by invertebrates: the Diamondback moth Plutella xylostella (Lepidoptera: Yponomeutidae) as a potential indicator species. Divers. Distrib. 8, 327-334.

Danthanarayana W, 1986. Lunar periodicity of insect flight and migration. In: Insect flight dispersal and migration. A symposium held at the XVII International Congress of Entomology, 1984. Ed. by Danthanarayana W, Springer-Verlag, New York, 88-119.

ECMWF, 2009. European Centre for medium-range weather forecasts. [WWW document]. URL http:// www.ecmwf.int/.

Gatehouse AG, 1997. Behavior and ecological genetics of wind-borne migration by insects. Annu. Rev. Entomol. 42, 475-502.

IPCC, 2007. Summary for policymakers. In: Climate change 2007: the physical science basis. Contribution of Working Group I to the Fourth Assessment Report of the Intergovernmental Panel on Climate Change. Ed. by Solomon S, Qin D, Manning M, Chen Z, Marquis M, Averyt K, Tignor M, Miller M, Cambridge University Press, Cambridge, UK/New York, NY, USA, 8.

Irwin ME, Thresh JM, 1988. Long range aerial dispersal of cereal aphids as virus vectors in North America. Philos. Trans. R. Soc. Lond. B Biol. Sci. 321, 421-446.

Kurppa S, 1989a. Predicting outbreaks of Rhopalosiphum padi in Finland. Ann. Agric. Fenn. 28, 333-347.

Kurppa S, 1989b. Damage and control of Rhopalosiphum padi in Finland during the outbreak of 1988. Ann. Agric. Fenn. 28, 349-370.

Lang TJ, Rutledge SA, Stith JL, 2004. Observations of quasi-symmetric echo patterns in clear air with
CSU-CHILL polarimetric radar. J. Atmos. Oceanic Technol. 21, 1182-1189.

Lim S, Chandrasekar V, Bringi V, 2005. Hydrometeor classification system using dual-polarization radar measurements: model improvements and in situ verification. IEEE Trans. Geosci. Remote Sens. 43, 792-801.

Luonnontieteellinen Keskusmuseo, 2009. Hyönteistietokanta [WWW document]. URL http://www.fmnh.helsinki.fi/insects/main/EntDatabase.html.

Mikkola K, 1967. Immigrations of Lepidoptera, recorded in Finland in the years 1946-1966, in relation to aircurrents. Ann. Entomol. Fenn. 33, 65-99.

Mikkola K, 1996. Sää ja hyönteisten vaellukset 1995 (Abstract in English: weather and migrations of insects in 1995 in Finland). Baptria 21, 133-140.

Mikkola K, 2003. The Red admiral butterfly (Vanessa atalanta, Lepidoptera: Nymphalidae) is a true seasonal migrant: an evolutionary puzzle resolved? Eur. J. Entomol. 100, 625-626.

Mikkola K, Salmensuu P, 1965. Migration of Laphygma exigua $\mathrm{Hb}$. (Lep., Noctuidae) in Northwestern Europe in 1964. Ann. Zool. Fenn. 2, 124-139.

Mueller EA, Larkin RP, 1985. Insects observed using dualpolarization radar. J. Atmos. Oceanic Technol. 2, 49-54.

Nieminen M, Leskinen M, Helenius J, 2000. Doppler radar detection of exceptional mass-migration of aphids into Finland. Int. J. Biometeorol. 44, 172-181.

Otuka A, Watanabe T, Suzuki Y, Matsumura M, Furuno A, Chino M, Kondo T, Kamimuro T, 2006. A migration analysis of Sogatella furcifera Horvath (Homoptera: Delphacidae) using hourly catches and a three-dimensional simulation model. Agric. For. Entomol. 8, 35-47.

Riley JR, 1975. Collective orientation in night-flying insects. Nature 253, 113-114.

Riley JR, 1985. Radar cross section of insects. Proc. IEEE 73, 228-232.

Riley JR, 1989. Remote sensing in entomology. Ann. Rev. Entomol. 34, 247-271.

Riley JR, Reynolds DR, Mukhopadhyay S, Ghosh MR, Sarkar TK, 1995. Long-distance migration of aphids and other small insects in northeast India. Eur. J. Entomol. 92, 639-653.

Scott RW, Achtemeier GL, 1987. Estimating pathways of migrating insects carried in atmospheric winds. Environ. Entomol. 16, 1244-1254.

Showers WB, 1997. Migratory ecology of the black cutworm. Annu. Rev. Entomol. 42, 393-425.

Siljamo P, Sofiev M, Severova E, Ranta H, Polevova S, 2007. On influence of long-range transport of pollen grains onto pollinating seasons. In: Developments in environmental science. Air Polution Modelling and Its Applications XVIII, Vol. 6. Ed. by Borrego C, Renner E, Elsevier, Amsterdam, 708-716. DOI: 10.1016/S14748177(70)06074-3. 
Siljamo P, Sofiev M, Severova E, Ranta H, Kukkonen J, Polevova S, Kubin E, Minin A, 2008a. Sources, impact and exchange of early-spring birch pollen in the Moscow region and Finland. Aerobiologia 24, 211-230.

Siljamo P, Sofiev M, Linkosalo T, Ranta H, Kukkonen J, 2008b. Development and application of biogenic emission term as a basis of long-range transport of allergenic pollen. In: Air Pollution Modelling and Its Application XIX, NATO Science for Peace and Security Series C: Environmental Security. Ed. by Borrego C, Miranda AI, Springer, Dordrecht, 154-162.

Smith AD, Reynolds DR, Riley JR, 2000. The use of vertical-looking radar to continuously monitor the insect fauna flying at altitude over southern England. Bull. Entomol. Res. 90, 265-277.

Sofiev M, Siljamo P, Ranta H, Rantio-Lehtimäki A, 2006a. Towards numerical forecasting of long-range air transport of birch pollen: theoretical considerations and a feasibility study. Int. J. Biometeorol. 50, 392-402.

Sofiev M, Siljamo P, Valkama I, Ilvonen M, Kukkonen J, 2006b. A dispersion modelling system SILAM and its evaluation against ETEX data. Atmos. Environ. 40, 674-685.

Sofiev M, Galperin M, Genikhovich E, 2008. A construction and evaluation of Eulerian dynamic core for the Air Quality and Emergency Modelling System SILAM. In: Air Pollution Modelling and Its Application XIX. NATO Science for Peace and Security Series - C: Environmental Security. Ed. by Borrego C, Miranda AI, Springer, Dordrecht, 699-701.

Taylor LR, 1962. The absolute efficiency of insect suction traps. Ann. Appl. Biol. 50, 405-421.

Tiilikkala K, Vasarainen A, Koistinen J, Salonoja M, 1996. Monitoring of the migration of the diamondback moth. In: Remote sensing in agriculture: reports of the Finnish geodetic institute. Ed. by R. Kuittinen, Proceedings, NJF Seminar 1996. Suom. Geod. Lait. Tiedon 96, 78-81.

Unden P, Rontu L, Jarvinen H, Lynch P, Calvo J, Cats G, Cuxart J, Eerola K, Fortelius C, Garcia-moya A, Jones C, Lenderlink G, Mcdonald A, Mcgrath R, Navascues B, Woetman Nielsen N, Degaard V, Rodriguez E,
Rummukainen M, Sattler K, Sass H, Savijarvi H, Wichers Schreur B, Sigg R, The H, Tijm A, 2002. HIRLAM-5 scientific documentation. December 2002. SMHI, Norrköping, Sweden.

Vanhanen H, Veteli T, Päivinen S, Kellomäki S, Niemelä $\mathrm{P}, 2007$. Climate change and range shifts in two insect defoliators: gypsy moth and nun moth - a model study. Silva Fenn. 41, 621-638.

Vaughn CR, 1985. Birds and insects as radar targets: a review. Proc. IEEE 73, 205-227.

Westbrook JK, Eyster RS, Wolf WW, Lingren PD, Raulston JR, 1995a. Migration pathways of Corn earworm (Lepidoptera: Noctuidae) indicated by tetroon trajectories. Agric. For. Meteorol. 73, 67-87.

Westbrook JK, Raulston JR, Wolf WW, Pair SD, Eyster RS, Lingren PD, 1995b. Field observations and simulations of atmospheric transport of noctuids from northeastern Mexico and the south-central U.S. Southwestern Entomologist. (Suppl. No. 18), 25-44.

Wiktelius S, 1981. Diurnal flight periodicities and temperature thresholds for flight for different migrant forms of Rhopalosiphum padi L. (Hom., Aphididae). Z. Angew. Entomol. 92, 449-457.

Wiktelius S, 1982. Flight and settling behaviour of Rhopalosiphum padi (L.) (Hemiptera: Aphididae). Bull. Entomol. Res. 72, 157-163.

Wilson JW, Weckwerth TM, Vivekanandan J, Wakimoto RM, Russell RW, 1994. Boundary layer clear-air radar echoes: origin of echoes and accuracy of derived winds. J. Atmos. Oceanic Technol. 11, 1184-1206.

Wolf RA, Pedigo LP, Shaw RH, Newsom LD, 1987. Migration/transport of the Green cloverworm, Plathypena scabra (F.) (Lepidoptera: Noctuidae), into Iowa as determined by synoptic-scale weather patterns. Environ. Entomol. 16, 1169-1174.

Wood CR, O'Connor EJ, Hurley RA, Reynolds DR, Illingworth AJ, 2009. Cloud-radar observations of insects in the UK convective boundary layer. Meteorol. Appl. 146, DOI: 10.1002/met. [online].

Zrnic DS, Ryzhkov AV, 1998. Observation of insects and birds with a polarimetric radar. IEEE Trans. Geosci. Remote Sens. 36, 661-668. 